\title{
BERAT LAHIR SEBAGAI FAKTOR DOMINAN TERJADINYA STUNTING PADA BALITA (12-59 BULAN) DI SUMATERA (ANALISIS DATA RISKESDAS 2010)
}

\author{
Fitri \\ Jurusan Gizi, Politeknik Kesehatan Kemenkes Riau \\ fitri.anwar06@gmail.com
}

\begin{abstract}
Stunting is very short state of body so that the deficit exceeded-2 SD below the median length or height. Stunting is a public health issue because it deals with an increased risk of morbidity and mortality, delayed motor development, and mental growth retardation. The general objective of research is to know the dominant factor related with stunting in infants (12-59 months) in Sumatra in 2010. This study uses cross sectional research design and quantitative method with 3126 toddlers sample. Processing and analyzing data using chi square test (bivariate) and multiple logistic regression (multivariate). The analysis showed that based on the index $T B / U$, stunting toddlers as much as $37.5 \%$ and $62.5 \%$ of normal. The results of chi square test showed significant relationship between stunting with birth weight, energy intake, protein intake, sex, maternal education, area of residence and economic status of families. The results of multivariate analysis showed the birth weight variable is the most dominant factor associated with stunting after being controlled with sex, area of residence and economic status of families variables.
\end{abstract}

Key words: stunting, birth weight, toddlers 12-59 months.

\section{PENDAHULUAN}

Diabetes melitus adalah salah satu penyakit atau kelainan metabolisme yang paling sering dijumpai dalam masyarakat. Diabetes melitus ini merupakan penyakit degeneratif yaitu penyakit akibat fungsi atau struktur dari jaringan atau organ tubuh yang secara progresif menurun karena usia atau pengaruh gaya hidup. Penderita diabetes pada umumnya menjalani hiperglikemia.

Keadaan gizi kurang dapat ditemukan pada setiap kelompok masyarakat. Pada hakikatnya keadaan gizi kurang dapat dilihat sebagai suatu proses kurang asupan makanan ketika kebutuhan normal terhadap satu atau beberapa zat gizi tidak terpenuhi, atau zat-zat gizi tersebut hilang dengan jumlah yang lebih besar daripada yang diperoleh. Stunting merupakan keadaan tubuh yang pendek dan sangat pendek hingga melampaui defisit -2 SD di bawah median panjang atau tinggi badan (Manary $\&$ Solomons, 2009).

Stunting dapat didiagnosis melalui indeks antropometrik tinggi badan menurut umur yang mencerminkan pertumbuhan linier yang dicapai pada pra dan pasca persalinan dengan indikasi kekurangan gizi jangka panjang, akibat dari gizi yang tidak memadai dan atau kesehatan. Stunting merupakan pertumbuhan linear yang gagal untuk mencapai potensi genetik sebagai akibat dari pola makan yang buruk dan penyakit (ACC/SCN, 2000).

Retardasi pertumbuhan atau stunting pada anak-anak di negara berkembang terjadi terutama sebagai akibat dari kekurangan gizi kronis dan penyakit infeksi 
yang mempengaruhi $30 \%$ dari anak-anak usia di bawah lima tahun (UNSCN, 2004). Stunting berhubungan dengan perkembangan yang buruk pada balita dan berakibat berkurangnya pengetahuan serta prestasi sekolah dibandingkan dengan anakanak yang normal. Stunting dapat mengakibatkan terganggunya fungsi kognitif, terganggunya proses metabolisme, dan terjadinya penurunan produktivitas (Branca \& D'Acapito, 2005).

Stunting adalah masalah gizi utama yang akan berdampak pada kehidupan sosial dan ekonomi dalam dan di antara masyarakat. Ada bukti jelas bahwa individu yang stunting memiliki tingkat kematian lebih tinggi dari berbagai penyebab dan terjadinya peningkatan penyakit. Stunting akan mempengaruhi kinerja pekerjaan fisik dan fungsi mental dan intelektual akan terganggu (Mann \& Truswell, 2002). Hal ini juga didukung oleh Jackson \& Calder (2004) mengatakan bahwa stunting berhubungan dengan gangguan fungsi kekebalan dan akan meningkatkan risiko kematian.

Adanya 178 juta anak di dunia yang terlalu pendek berdasarkan usia dibandingkan dengan pertumbuhan standar WHO, stunting menjadi indikator kunci dari kekurangan gizi kronis, seperti pertumbuhan yang melambat, perkembangan otak tertinggal dan sebagai hasilnya anak-anak stunting lebih mungkin mempunyai daya tangkap yang lebih rendah. Tingkat stunting antara anak-anak di Afrika dan Asia sangat bervariasi di antara beberapa studi yang dipublikasikan (WHO, 2011).

Prevalensi stunting di beberapa negara di Afrika, di Asia, di Amerika Selatan dan Tengah dan di Karibia berkisar antara 30$50 \%$ (misalnya Bolivia, Guatemala, Haiti, Honduras, Peru). Prevalensi stunting pada anak-anak berusia di bawah lima tahun di Guatemala mengalami peningkatan bisa dilihat dari tahun 1998 prevalensi stuntingnya 53,1\% dan pada tahun 2002 menjadi 54,3\%. Begitu juga dengan Haiti mengalami peningkatan dari tahun 2000 prevalensi stuntingnya $28,3 \%$ menjadi 29,7\% pada tahun 2006 dan Peru walaupun terjadi penurunan dibandingkan dengan tahun 1996 yaitu 31.6\% prevalensi stunting di Peru masih berada di kisaran $30 \%$ pada tahun 2005 (UNSCN, 2008).

Kekurangan gizi di kalangan anak-anak masih umum di banyak bagian dunia. Di Afrika, peningkatan prevalensi di tambah dengan pertumbuhan penduduk menyebabkan peningkatan jumlah anak kurus dari 24 juta di tahun 1990 menjadi 30 juta di 2010. Di Asia, jumlah anak kurus diperkirakan akan lebih besar sekitar 71 juta pada tahun 2010 (WHO, 2011). Prevalensi stunting tahun 2007 di Asia adalah $30.6 \%$ (UNSCN, 2008). Dan juga didukung oleh penelitian Sengupta, Phillip \& Benjamin (2010) yang dilakukan di Ludhiana, India, prevalensi stunting pada usia 12 - 59 bulan adalah $74.55 \%$. Indonesia adalah salah satu negara yang termasuk prevalensi dari stunting kategori sangat tinggi yaitu lebih dari 40\% (WHO, 1997).

Hasil Riset Kesehatan Dasar (Riskesdas) tahun 2010 menunjukkan bahwa dalam beberapa tahun terakhir telah terjadi perbaikan status gizi balita di Indonesia. Hal ini ditandai dengan menurunnya prevalensi stunting dari $36.5 \%$ pada tahun 2007 menjadi sebesar 35,6 \% pada tahun 2010 . Angka prevalensi ini masih diatas ambang batas (cut off) yang telah disepakati secara universal, dimana apabila masalah stunting diatas $20 \%$ maka masih merupakan masalah kesehatan masyarakat (Kemenkes RI, 2010).

WHO (1997) mengelompokkan wilayah berdasarkan prevalensi stunting ke dalam empat kelompok yaitu rendah (< 20\%), sedang $(20-29 \%)$, tinggi $(30-39 \%)$ dan 
sangat tinggi (> 40\%). Menurut Riskesdas (2010) angka prevalensi stunting pada balita di Sumatera yaitu sebesar $34.1 \%$. Terdapat empat propinsi di Sumatera dengan prevalensi stunting di atas prevalensi nasional yaitu Aceh (39\%), Sumatera Utara (42.3\%), Sumatera Selatan (40.4\%) dan Lampung (36.2\%). Terdapat dua propinsi yang prevalensi stunting sangat tinggi yaitu $>40 \%$ adalah Sumatera Utara dan Sumatera Selatan. Berdasarkan angka prevalensi tersebut diketahui bahwa kejadian stunting di Sumatera termasuk tinggi. Oleh karena itu diperlukan suatu penelitian untuk mengidentifikasi faktor-faktor yang mempengaruhi kejadian stunting di Sumatera.

Berdasarkan uraian tersebut diatas, penulis tertarik untuk menulis tentang Berat Lahir Sebagai Faktor Dominan Terjadinya Stunting Pada Balita (12-59 Bulan) Di Sumatera (Analisis Data Riskesdas 2010).

\section{METODOLOGI PENELITIAN Desain Penelitian}

Desain yang digunakan dalam penelitian ini adalah cross sectional (potong lintang) dengan pendekatan kuantitatif dengan tujuan untuk mengetahui faktor dominan yang berhubungan dengan stunting pada balita (12 - 59 Bulan) di Sumatera tahun 2010. Stunting pada balita merupakan variabel dependen sedangkan variabel independen yang diteliti adalah berat lahir, asupan energi, asupan protein, umur dan jenis kelamin balita, pendidikan ibu, jumlah anggota rumah tangga, wilayah tempat tinggal dan status ekonomi keluarga.

\section{Waktu dan Lokasi Penelitian}

Riskesdas telah dilaksanakan pada bulan Mei - Agustus 2010 di 33 Provinsi dan 441 kabupaten/kota dari total 497 kabupaten/kota di Indonesia. Pelaksanaan analisis data untuk penulisan ini dilaksanakan pada bulan September Desember 2011 di Fakultas Kesehatan Masyarakat - Universitas Indonesia, Depok - Jawa Barat. Penelitian ini menggunakan data sekunder dari Riskesdas 2010 yang mengambil lokasi penelitian di Sumatera. Prosedur perijinan telah diajukan dari Fakultas Kesehatan Masyarakat Universitas Indonesia kepada Badan Penelitian dan Pengembangan Kemenkes R.I. pada bulan Juni 2011.

\section{Populasi dan Sampel Penelitian}

Populasi adalah balita yang terdapat pada data Riskesdas 2010 diwilayah blok sensus Sumatera yang hidup pada saat dilakukan wawancara. Berdasarkan data yang diperoleh dari Badan Penelitian dan Pengembangan Kesehatan Kementerian Kesehatan RI, jumlah balita yang terdapat pada data Riskesdas 2010 di wilayah blok sensus Sumatera adalah 5392 orang. Sedangkan sampel adalah bayi yang mempunyai data lengkap sesuai variabel penelitian (tidak ada yang missing). Balita yang diambil sebagai sampel penelitian ini adalah balita yang mempunyai kriteria sebagai berikut:

Kriteria inklusi adalah usia balita 12 59 bulan dan mempunyai data lengkap sesuai variabel penelitian.

Kriteria eksklusi adalah mempunyai data z score $\mathrm{TB} / \mathrm{U}<-6 \mathrm{SD}$ dan $>+6 \mathrm{SD}$ (WHO, 2010).

Berdasarkan kriteria tersebut maka diperoleh anak usia 12 - 59 bulan yang mempunyai data $\mathrm{z}$ score $\mathrm{TB} / \mathrm{U}$ lengkap sebanyak 3126 anak.

\section{Kekuatan Uji Penelitian}

Penelitian ini menggunakan data riskesdas 2010 yang merupakan data sekunder, sehingga besar sampel sudah diketahui terlebih dahulu. Pada penelitian ini sampel yang memenuhi kriteria inklusi dan eksklusi adalah sebanyak 3126 orang. 
Perhitungan kekuatan uji variabel-variabel penelitian akan digunakan rumus besar sampel yaitu rumus uji hipotesis untuk dua proporsi. Berdasarkan proporsi variabel yang diperoleh dari penelitian dengan menggunakan sampel 3126 orang, dihitung kekuatan uji (1- $\beta$ ) penelitian pada masingmasing variabel dalam penelitian ini dan diperoleh nilai (1- $\beta$ ) lebih besar dari 80\%. menurut indeks $\mathrm{PB} / \mathrm{U}$ (12-24 Bulan) dan TB/U (24 - 59 Bulan) adalah 37.5\% dan yang mempunyai status gizi normal sebesar $62.5 \%$. Sebagian besar balita mempunyai berat lahir normal (95.2\%) sedangkan balita lainnya mempunyai berat lahir rendah yaitu sebesar $4.8 \%$. Distribusi responden menurut karakteristik variabel penelitian secara lengkap disajikan pada Tabel 1.

\section{HASIL DAN PEMBAHASAN}

Hasil penelitian menunjukkan prevalensi stunting pada balita (12-59 bulan)

Tabel 1. Hasil Analisis Univariat

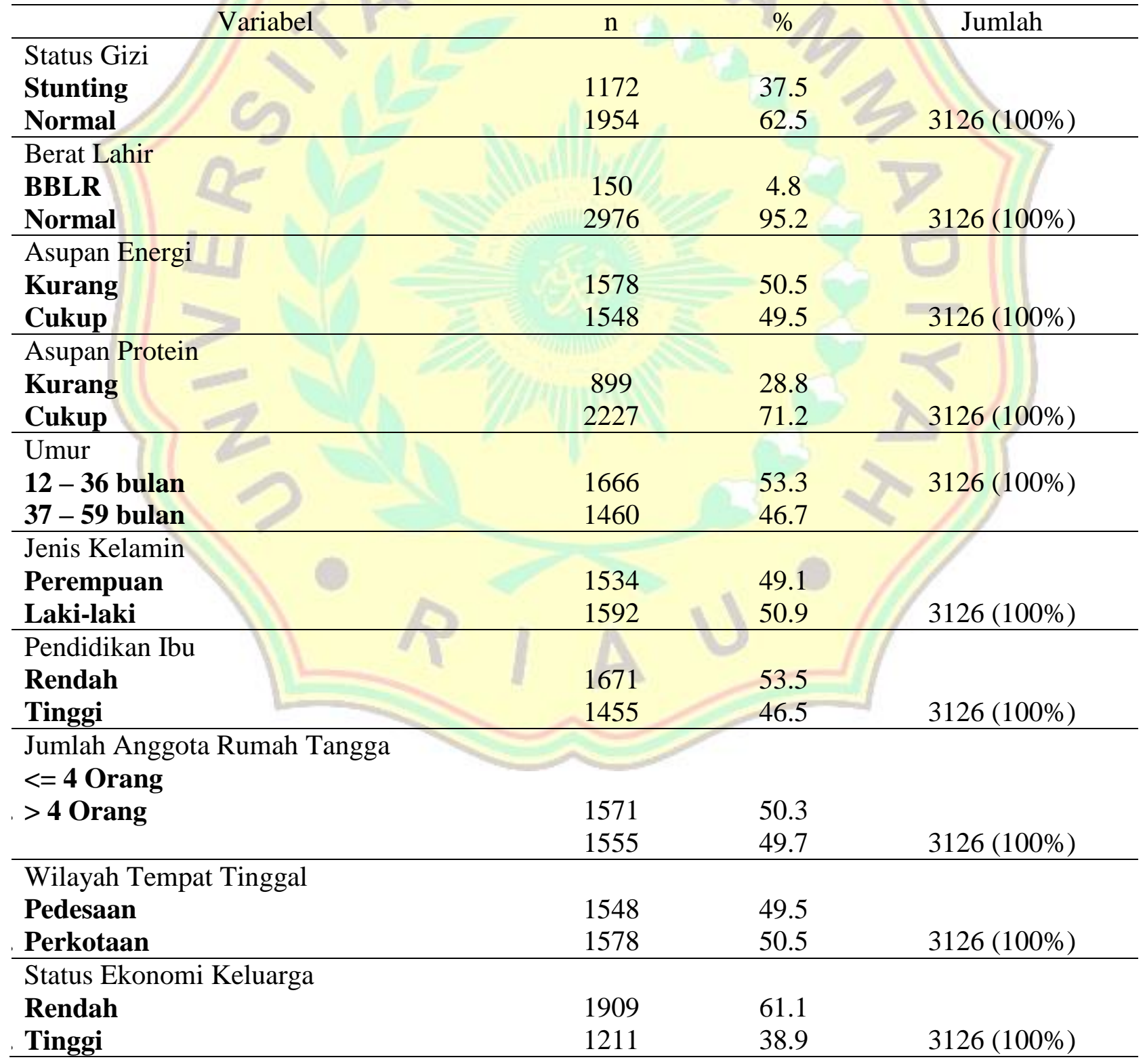


Hubungan Karakteristik Responden dengan Stunting

Proporsi kejadian stunting pada balita (12 - 59 bulan) lebih banyak ditemukan pada balita dengan berat lahir rendah $(49.3 \%)$ dibandingkan balita dengan berat lahir normal (36.9\%). Terdapat hubungan yang bermakna secara statistik antara berat lahir dengan stunting yang diukur berdasarkan indeks status gizi TB/U dengan $\mathrm{p}$ value 0.003 dan nilai OR sebesar 1.665. Hal ini berarti bahwa balita yang mempunyai berat lahir rendah, memiliki risiko menjadi stunting sebesar 1.7 kali dibanding balita yang mempunyai berat lahir normal. Hasil analisis bivariat variable independent dengan variabel dependent pada penelitian secara lengkap disajikan pada Tabel 2.

Tabel 2. Hasil Analisis Bivariat

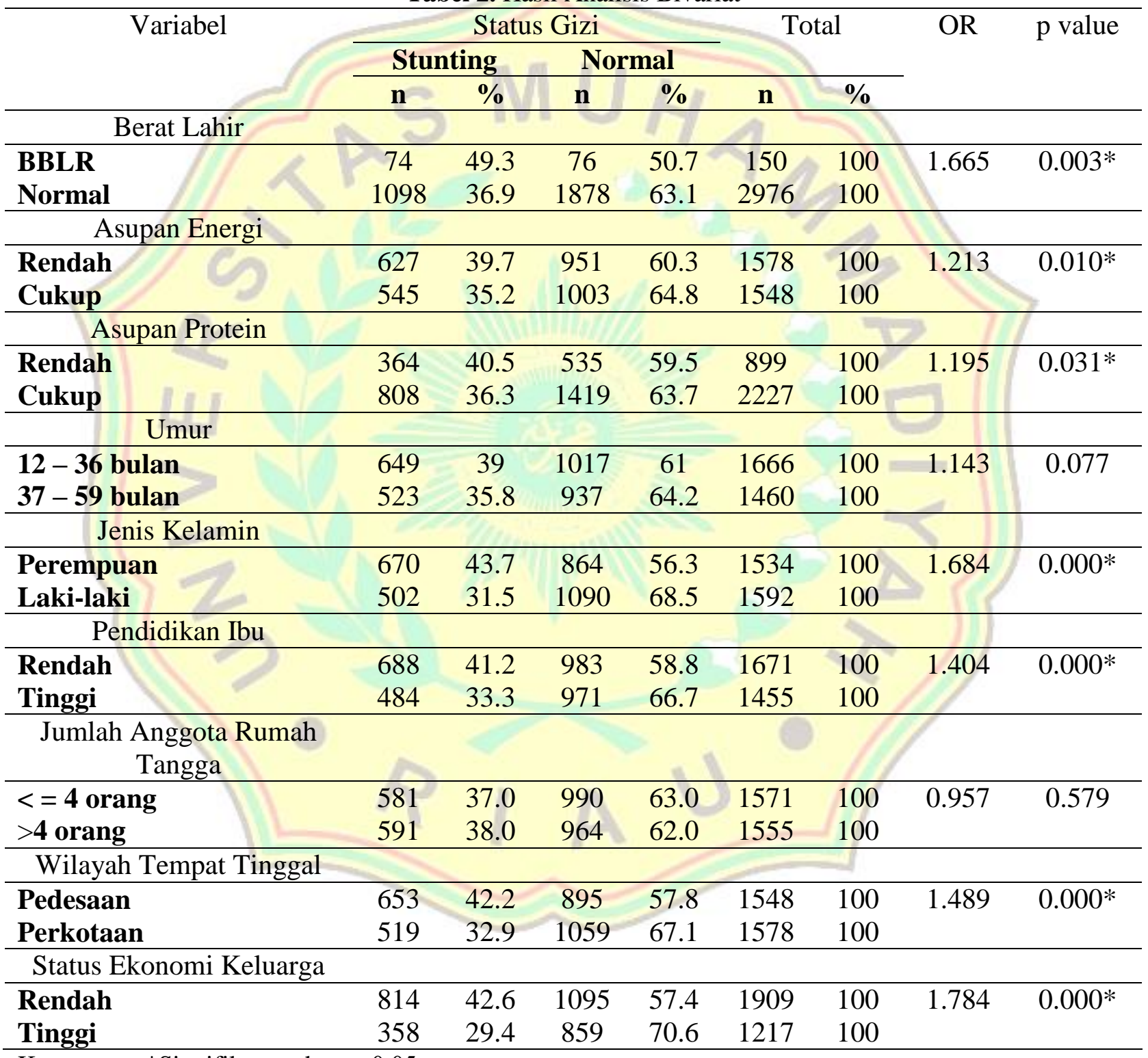

Keterangan:*Signifikan pada $\alpha=0.05$

\section{Analisis Multivariat}

Hasil analisis bivariat antara variabel independen dengan variabel dependen diketahui bahwa ada 8 variabel yang nilai $p$ value $<0.25$ yaitu variabel berat lahir, asupan energi, asupan protein, umur, jenis kelamin, pendidikan ibu, tempat tinggal dan status ekonomi keluarga.. Hasil akhir dari 
analisis multivariat dapat dilihat

selengkapnya pada tabel 3 .

Tabel 3. Pemodelan Terakhir Analisis Multivariat

\begin{tabular}{lccc}
\hline \multicolumn{1}{c}{ Variabel } & $\operatorname{Exp}(\mathrm{B})$ & $\mathrm{p}$-value & OR (95\% CI) \\
\hline Berat Lahir & 1.707 & 0.002 & $1.220-2.389$ \\
Jenis Kelamin & 1.681 & 0.000 & $1.450-1.950$ \\
Wilayah Tempat Tinggal & 1.322 & 0.000 & $1.136-1.539$ \\
Status Ekonomi Keluarga & 1.678 & 0.000 & $1.431-1.967$ \\
\hline
\end{tabular}

Penelitian ini merupakan penelitian menggunakan data sekunder yang dihasilkan Riskesdas 2010. Data konsumsi makanan yaitu asupan energi balita hanya berdasarkan hasil recall 1 x 24 jam. Menurut Gibson (2005), recall konsumsi makanan sebaiknya dilakukan 3 x 24 jam dengan tujuan untuk menangkap variasi dalam jenis dan jumlah konsumsi makanan. Asupan energi yang berasal dari ASI tidak dihitung, tetapi yang dihitung hanya asupan yang berasal konsumsi makanan selain ASI. Tingkat pendapatan keluarga dihitung berdasarkan jumlah pengeluaran rumah tangga sehari yang dinyatakan dalam kuintil (1 sampai dengan 5). Angka dalam rupiah untuk kuintil-kuintil tersebut tidak bisa didapatkan oleh penulis karena data tersebut tidak ada dalam data Riskesdas 2010.

Prevalensi stunting di Sumatera sebesar $37.5 \%$, lebih tinggi dari prevalensi stunting nasional hasil Riskesdas 2010 sebesar $35.6 \%$. Bila dibandingkan dengan batas "non public health problem" menurut WHO, angka ini masih di atas ambang batas (cut off) yang telah disepakati secara universal. Apabila masalah stunting di atas 20\% maka merupakan masalah kesehatan masyarakat (Kemenkes RI, 2010).

Tingginya prevalensi stunting mengindikasikan bahwa pertumbuhan pada anak terkait dengan faktor jangka panjang, termasuk tidak cukupnya asupan makanan, infeksi, tidak menyusui selama periode yang berkelanjutan, dan rendahnya status sosial ekonomi rumah tangga. Ini cukup terbukti dalam penelitian yang dilakukan oleh El Sayed et al (2001) tingkat sosial ekonomi tinggi dan status lingkungan yang baik ditemukan menjadi protektif terhadap stunting.

Berat lahir merupakan indikator untuk kelangsungan hidup, pertumbuhan, kesehatan jangka panjang dan pengembangan psikososial dan juga mencerminkan secara mendasar kualitas perkembangan intra uterin dan pemeliharaan kesehatan mencakup pelayanan kesehatan yang diterima oleh ibu selama kehamilannya (Awwal et al, 2004). Berat bayi pada saat dilahirkan juga indikator potensial untuk pertumbuhan bayi, respon terhadap rangsangan lingkungan, dan untuk bayi bertahan hidup. Berat bayi $<2.500$ gram membawa risiko 10 kali dari kematian neonatal dibandingkan dengan bayi baru lahir beratnya 3 sampai $3,5 \mathrm{~kg}$ (Schanler, 2003).

Penelitian ini menunjukkan bahwa proporsi balita stunting lebih banyak ditemukan pada balita dengan berat lahir rendah dibandingkan balita dengan berat lahir normal. Terdapat perbedaan proporsi antara keduanya, balita yang mempunyai berat lahir rendah memiliki risiko menjadi stunting sebesar 1.7 kali dibanding balita yang mempunyai berat lahir normal.

Berat lahir rendah merupakan faktor risiko yang sangat signifikan untuk pertumbuhan, terutama di 6 bulan pertama. Sepanjang dua tahun pertama, infeksi meningkatkan kemungkinan stunting, dan 
perawatan kesehatan memiliki efek perlindungan (Adair \& Guilkey, 1997). Berat bayi lahir rendah yang diikuti oleh asupan makanan dan pelayanan kesehatan yang tidak memadai, sering terjadi infeksi pada anak selama masa pertumbuhan menyebabkan pertumbuhan anak akan terhambat dan anak akhirnya menjadi pendek (stunting) (ACC/SCN, 2000). Infeksi yang sering terjadi pada balita adalah diare dan infeksi saluran pernafasan. Infeksi pada balita tergantung kondisi lingkungan dan kebersihan tempat tinggal di sekitar balita.

Bayi lahir cukup bulan (37 minggu kehamilan), tetapi berat lahir rendah $(<2500$ gr) mengalami pertumbuhan intrauterin terbatas. Dengan teknik regresi linier untuk memperkirakan hubungan antara berat lahir dan angka kematian, risiko relatif untuk semua penyebab kematian dan untuk kematian karena asfiksia lahir dan infeksi. Bayi lahir dengan berat 1500-1999 gram, 8,1 (95\%CI: 3.3 -19.3) kali lebih risiko meninggal, dan bayi dengan berat 20002499 gr dan 2,8 (95\%CI: 1,8 - 4,4) kali lebih risiko meninggal akibat semua penyebab selama periode neonatal, dibandingkan bayi dengan berat lahir > 2499 gr (Black et al, 2008).

Berat lahir sangat tergantung pada status gizi ibu selama kehamilan dan sebelum konsepsi. Berat lahir juga menjadi indikator tidak langsung untuk mengevaluasi gizi ibu dan sampai titik tertentu, untuk memprediksi perkembangan masa depan anak. Anak-anak dengan pertumbuhan terhambat berisiko menjadi gemuk, sehingga menempatkan mereka pada peningkatan risiko mengembangkan penyakit kronis di masa dewasa (PAHO, 2007). Hal ini dapat disebabkan oleh peranan hormon leptin dan insulin yang mengatur penyimpanan dan keseimbangan energi. Leptin memegang peran utama sebagai pengendali berat badan.
Apabila asupan energi melebihi dari yang dibutuhkan, maka jaringan adiposa meningkat disertai dengan peningkatan kadar leptin dalam peredaran darah sehingga terjadi penurunan nafsu makan. Demikian pula sebaliknya bila kebutuhan energi lebih besar dari asupan energi, maka jaringan adiposa berkurang dan terjadi rangsangan pada orexigenic center di hipotalamus yang menyebabkan peningkatan nafsu makan.

Ukuran tubuh ibu sebelum hamil, yang mencerminkan status gizi ibu prakehamilan, adalah prediktor kuat dari berat lahir, pertumbuhan bayi dan status gizi ibu postpartum. Kekurangan gizi kronis ringan dan sedang mengarah ke stunting pada awal kehidupan. Dengan usia tiga sampai empat bulan, anak-anak mulai menderita kerugian permanen dalam potensi mereka untuk pertumbuhan dan perkembangan normal. Anak stunting lebih rentan terhadap penyakit daripada anak-anak normal (Lachance, P. A. 1995). Hal ini dapat disebabkan oleh rendahnya daya tahan tubuh anak stunting daripada anak normal.

Hasil penelitian ini menunjukkan bahwa proporsi kejadian stunting pada balita lebih banyak ditemukan pada asupan energi kurang dibandingkan balita dengan asupan energi cukup. Kedua proporsi berbeda nyata secara statistik. Balita yang mempunyai asupan energi kurang, memiliki risiko menjadi stunting sebesar 1.2 kali dibanding balita yang mempunyai asupan energi cukup.

Kegagalan pertumbuhan (stunting) dihasilkan dari kurangnya asupan gizi merupakan faktor risiko yang paling besar dalam menentukan perkembangan anak (Wachs, 2008). Kekurangan gizi mempengaruhi sejumlah besar anak-anak di negara berkembang. Kekurangan gizi akibat dari berbagai faktor, sering terkait buruknya kualitas makanan, asupan makanan tidak 
cukup, dan penyakit infeksi (El Sayed et al, 2001).

Berdasarkan penelitian Hautvast et al (1999) dengan sampel bayi umur 6-9 bulan dan anak usia 14-20 bulan menemukan bahwa asupan harian total energi tidak cukup dibandingkan dengan asupan harian yang direkomendasikan bagi bayi dan balita. Bayi dan balita yang stunting cenderung memiliki asupan energi rendah dibandingkan dengan yang tidak stunting. Asupan energi harian per $\mathrm{kg}$ berat badan tidak menunjukkan perbedaan antara stunting dan tidak stunting pada anak-anak.

Dengan tidak adanya gizi yang memadai, tubuh anak akan menghemat energi dengan membatasi kenaikan berat badan dan kemudian membatasi pertumbuhan linier. Studi cross-sectional dan longitudinal dari beberapa negara telah menemukan hubungan antara stunting dan kesehatan serta perkembangan anak, yang disebabkan oleh banyak faktor seperti kekurangan gizi dan infeksi. Konsekuensi yang terkait dengan stunting dini termasuk perubahan metabolisme, fungsi kekebalan, morbiditas, kematian, keterampilan motorik tertunda, nilai kognitif yang rendah, dan prestasi yang buruk dalam akademis (Darity, 2008).

Protein merupakan faktor utama dalam jaringan tubuh. Protein membangun, memelihara, dan memulihkan jaringan di tubuh, seperti otot dan organ. Saat anak tumbuh dan berkembang, protein adalah gizi yang sangat diperlukan untuk memberikan pertumbuhan yang optimal. Asupan protein harus terdiri sekitar $10 \%$ sampai $20 \%$ dari asupan energi harian (Sharlin \& Edelstein, 2011).

Hasil penelitian menunjukkan bahwa proporsi kejadian stunting pada balita lebih banyak ditemukan pada asupan protein kurang dibandingkan balita dengan asupan protein cukup. Balita yang mempunyai asupan protein kurang, memiliki risiko menjadi stunting sebesar 1.2 kali dibanding balita yang mempunyai asupan protein cukup.

Peningkatan asupan energi protein diperlukan untuk bayi dan anak-anak stunting yang perlu tumbuh dalam rangka untuk mengejar ketinggalan. Kekurangan gizi selama tahun pertama kehidupan, baik hasil dari lingkungan atau maupun karena kondisi seperti malabsorpsi atau cystic fibrosis. Peningkatan kebutuhan protein untuk mengejar pertumbuhan secara proporsional lebih besar dari peningkatan energi dan tergantung pada usia dan kecepatan pertumbuhan (Lawson, 2005).

Variabel umur penelitian ini dikategorikan menjadi dua yaitu kelompok umur 12 - 36 bulan dan kelompok umur 37 - 59 bulan. Pengelompokan tersebut didasarkan pada masa kritis dalam proses pertumbuhan.

Hasil penelitian ini menunjukkan proporsi kejadian stunting pada balita lebih banyak ditemukan pada kelompok umur 12 - 36 bulan dibandingkan kelompok umur 37 - 59 bulan. Hal ini sesuai dengan penelitian Teshome et al (2009) proporsi stunting tertinggi ditemukan pada kelompok umur 13 - 24 bulan $(51 \%)$ dan yang paling rendah pada kelompok umur $0-6$ bulan (16.7\%). Stunting merupakan sebuah proses kumulatif yang dimulai di dalam rahim dan terus sampai sekitar tiga tahun setelah kelahiran. Periode dua tahun pertama kehidupan sebagai masa yang paling kritis dalam proses pertumbuhan. Laju pertumbuhan pada tahun pertama kehidupan adalah lebih cepat dibandingkan pada usia lainnya. Antara kelahiran dan usia 1 tahun, panjang badan anak-anak rata-rata meningkat dengan $50 \%$, menjadi tiga kali berat lahir mereka. Analisis statistik menunjukkan bahwa tidak 
ada hubungan secara statistik antara umur balita dengan stunting ( $\mathrm{p}>0.05$ ).

Hasil penelitian ini menunjukkan proporsi kejadian stunting pada balita lebih banyak ditemukan pada jenis kelamin perempuan dibandingkan balita dengan jenis kelamin laki-laki. Terdapat hubungan yang bermakna secara statistik antara jenis kelamin dengan stunting. Balita dengan jenis kelamin perempuan, memiliki risiko menjadi stunting sebesar 1.7 kali dibanding balita dengan jenis kelamin laki-laki. Balita laki-laki lebih cenderung menjadi terhambat pertumbuhannya pada tahun pertama, sedangkan perempuan lebih mungkin untuk menjadi terhambat pada tahun kedua kehidupan (Adair \& Guilkey, 1997).

Hasil studi longitudinal yang dilakukan oleh Crookston et al (2010) yang diikuti dari umur $6-18$ bulan sampai $4.5-6$ tahun menemukan bahwa jenis kelamin berhubungan secara signifikan dengan stunting. Hasil studi longitudinal yang dilakukan oleh Bosch et al (2008) di Matlab, Bangladesh dengan 707 anak usia bawah lima tahun (387 anak laki-laki dan 320 anak perempuan) hingga berumur $12-13$ tahun menemukan kemungkinan terjadinya stunting pada masa remaja untuk anak perempuan adalah 0,4 kali kemungkinan untuk anak laki-laki. Hal ini berarti stunting pada masa remaja lebih berisiko pada anak laki-laki daripada anak perempuan.

Dalam penelitian ini juga terungkap bahwa anak perempuan lebih mungkin menjadi stunting dibandingkan anak lakilaki pada masa kecil, sedangkan anak lakilaki lebih mungkin menjadi stunting dibandingkan perempuan pada masa remaja. Perbedaan antara laki-laki dan perempuan mungkin berkaitan dengan efek gabungan dari perbedaan waktu percepatan pertumbuhan dan mungkin perbedaan dalam mengejar potensi dalam konteks kekurangan gizi. Anak perempuan memasuki masa puber lebih awal dari anak laki-laki, pertumbuhan mereka berhenti setidaknya dua tahun sebelum anak laki-laki, dan dua tahun juga mewakili perbedaan di puncak tinggi kecepatan antara kedua jenis kelamin (Bosch et al, 2008). Hal berbeda dikemukan oleh penelitian yang dilakukan oleh El Sayed et al (2001) dan Hong \& Mishra (2009) menyebutkan bahwa jenis kelamin tidak berhubungan secara signifikan dengan stunting pada balita.

Pendidikan ibu merupakan faktor yang sangat penting. Tinggi rendahnya tingkat pendidikan ibu erat kaitannya dengan tingkat pengetahuan terhadap perawatan kesehatan, proses kehamilan dan pasca persalinan, serta kesadaran terhadap kesehatan dan gizi anak-anak dan keluarganya. Tingkat pendidikan turut pula menentukan mudah tidaknya seseorang menyerap dan memahami pengetahuan gizi yang mereka peroleh. Pendidikan diperlukan agar seseorang lebih tanggap terhadap adanya masalah gizi didalam keluarga dan bisa mengambil tindakan secepatnya (Suhardjo, 2003).

Hasil analisis menunjukkan proporsi kejadian stunting pada balita lebih banyak ditemukan pada pendidikan ibu rendah dibandingkan pada pendidikan ibu tinggi. Balita yang mempunyai pendidikan ibu rendah, memiliki risiko menjadi stunting sebesar 1.4 kali dibanding balita yang mempunyai pendidikan ibu tinggi.

Studi yang dilakukan di negara berkembang juga mengidentifikasi tingkat pendidikan ibu berhubungan dengan pertumbuhan fisik dari anak. Salah satu jalur potensial melibatkan hubungan antara pendidikan ibu meningkat dan masukan yang lebih besar oleh ibu tentang keputusan alokasi sumber daya keluarga (Becker, Fonseca Becker, \& Yglesias, 2006) karena 
ibu lebih cenderung untuk mengalokasikan sumber daya keluarga dalam cara-cara mempromosikan gizi anak mereka. Tingkat pendidikan dapat meningkatkan keputusan ibu membuat kekuasaan, yang meningkatkan gizi anak, kesehatan dan akhirnya pertumbuhan fisik mereka (Wachs, 2008).

Hasil analisis menunjukkan bahwa proporsi kejadian stunting pada balita lebih banyak ditemukan pada jumlah anggota rumah tangga $>4$ orang dibandingkan balita dengan jumlah anggota rumah tangga $\leq 4$ orang. Meskipun terdapat perbedaan proporsi, hasil analisis menunjukkan tidak ada hubungan bermakna antara jumlah anggota rumah tangga dengan kejadian stunting pada balita.

Hasil penelitian menunjukkan proporsi kejadian stunting pada balita lebih banyak ditemukan di wilayah pedesaan dibandingkan di wilayah perkotaan. Balita yang tempat tinggalnya di pedesaan, memiliki risiko menjadi stunting sebesar 1.3 kali dibanding balita yang tempat tinggalnya di perkotaan. Stunting biasanya paling menonjol di daerah pedesaan dan ini merupakan indikasi yang berkaitan dengan kondisi lingkungan (WHO, 2003).

Hasil studi longitudinal yang dilakukan oleh Crookston et al (2010) yang diikuti dari umur $6-18$ bulan sampai $4.5-6$ tahun menemukan bahwa wilayah tempat tinggal berhubungan secara signifikan dengan stunting. Begitu juga dengan Hong \& Mishra (2009) menyebutkan bahwa wilayah tempat tinggal berhubungan secara signifikan dengan stunting pada balita. Bertolak belakang dengan penelitian El Sayed et al (2001) menyebutkan bahwa wilayah tempat tinggal tidak berhubungan secara signifikan dengan kejadian stunting.

Prevalensi stunting bervariasi di daerah pedesaan dan perkotaan. Anak-anak kekurangan gizi kronis lebih banyak ditemukan di daerah pedesaan. Hal ini dapat disebabkan status gizi kesehatan masyarakat di pedesaan jauh lebih rendah daripada status gizi di perkotaan. Susahnya mendapatkan pelayanan kesehatan di daerah pedesaan dan status sosial ekonomi yang rendah merupakan faktor yang menyebabkan status gizi balita di perkotaan dan pedesaan menjadi berbeda.

Proporsi kejadian stunting pada balita lebih banyak ditemukan pada status ekonomi keluarga rendah dibandingkan balita dengan status ekonomi keluarga tinggi. Balita dengan status ekonomi keluarga rendah, memiliki risiko menjadi stunting sebesar 1.7 kali dibanding balita dengan status ekonomi keluarga tinggi.

Stunting biasanya tinggi di tempattempat terjadinya perbedaan status sosial. Ketidaksetaraan sosial ekonomi berkaitan dengan ketersediaan pangan, kualitas makanan, kebersihan, ketersediaan kecukupan pasokan air minum dan pencegahan dan pengobatan penyakit infeksi (Biondi, 2007).

Penelitian yang dilakukan oleh Hong \& Mishra (2009) menyebutkan bahwa status ekonomi berhubungan secara signifikan dengan stunting pada balita. Pada penelitian status ekonomi dilihat dari perbedaan kuintil, yang dibagi kuintil 1 sampai kuintil 5. Prevalensi stunting menurun dengan meningkatnya status ekonomi rumah tangga. Prevalensi stunting biasanya terjadi pada 12 bulan pertama kehidupan (Hong, 2007).

\section{KESIMPULAN DAN SARAN}

1. Berdasarkan hasil analisis statistik dengan menggunakan uji chi square terhadap hubungan variabel independen dan stunting diperoleh hasil sebagai berikut: Terdapat hubungan yang signifikan proporsi stunting pada anak 
usia 12-59 bulan berdasarkan berat lahir, asupan energi, asupan protein, jenis kelamin, pendidikan ibu, wilayah tempat tinggal dan status ekonomi keluarga

2. Variabel independen yang paling dominan berhubungan dengan stunting pada balita adalah berat lahir setelah dikontrol variabel jenis kelamin, wilayah tempat tinggal dan status ekonomi keluarga.

\section{SARAN}

1. Berat lahir sangat menentukan pertumbuhan dan perkembangan balita selanjutnya sehingga perlu adanya perbaikan kualitas gizi ibu dalam mempersiapkan kehamilan.

2. Perlu adanya perbaikan status gizi balita dengan peningkatan konsumsi energi dan protein untuk mengurangi resiko terjadinya stunting pada balita.

3. Tingkat pendidikan ibu berhubungan dengan kejadian stunting pada balita sehingga perlunya tingkat pendidikan dasar minimal 12 tahun untuk meningkatkan pengetahuan ibu sehingga meminimalisir terjadinya stunting pada balita.

\section{DAFTAR PUSTAKA}

ACC/SCN \& International Food Policy Research Institute (IFPRI). (2000). 4th Report on The World Nutrition Situation, Nutrition Throughout The Life Cycle.

Adair, LS \& Guilkey, DK. (1997). Age Specific Determinant Of Stunting In Filipino Children. Community and International Nutrition. The Journal of Nutrition.

Black et al. (2008). Maternal And Child Undernutrition: Global And Regional Exposures And Health Consequences.
The Lancet Series. www.thelancet.com

Bosch A, B , Baqui, A. H. \& Ginneken, J. K .(2008). Early-life Determinants of Stunted Adolescent Girls and Boys in Matlab, Bangladesh. International Centre For Diarrhoeal Disease Research, Bangladesh. 2: 189 - 199.

Biondi, D. J. (2007). Nutrient Intake Adequacy and Child Stunting in Kabarole District, Western Uganda. Department of Public Health Sciences, University of Alberta. ProQuest Dissertations \& Theses.

Becker, S. Fonseca Becker, F \& Yglesias, C. S. (2006). Husbands' And Wives' Reports Of Women's Decisionmaking Power In Western Guatemala And Their Effects On Preventive Health Behaviors. Social Science and Medicine. 62: 2313-2326

Crookston, et al. (2010). Children Who Recover from Early Stunting and Children Who Are Not Stunted Demonstrate Similar Levels of Cognition. The Journal of Nutrition. ProQues.140 (11): 1996

Darity, W. A. (2008). Stunted Growth. International Encylopedia of The Social Sciences, 2 nd Edition. 8: 18789. Detroit Macmillan References USA.

El Sayed, et al. (2001). Malnutrition among Pre school Children in Alexandria, Egypt. Journal Health Popular Nutrition. Centre for Health and Population Research. 4: 275-280.

Gibson, R. S. (2005). Principles of Nutritional Assessment. Second Edition. Oxford University Press, Inc. New York.

Hong, R. (2007). Effect Of Economic Inequality On Chronic Childhood 
Undernutrition In Ghana. Public

Health Nutrition: 10(4), 371-378.

Hong, R. \& Mishra, V. (2009). Effect of Wealth Inequality on Chronic Undernutrition in Cambodian Children. J Health Popul Nutr, 24(1):89-99

Hautvast et al. (1999). Food Consumption of young stunted and non stunted children in rural Zambia. European Journal of Clinical Nutrition 53, 50 59. Stockton Press.

Kemenkes, RI. (2010). Riset Kesehatan

Dasar 2010. Badan Penelitian dan Pengembangan Kesehatan,

Kementerian Kesehatan RI.

Lawson, M. (2005). Encylopedia of Human Nutrition (Nutritional Requirement). Caballero, B, Allen, L \& Prentice, A (Ed). Elsevier Academic Press. 361.

Lachance, P. A. (1995). Recommended Dietary Allowance For Growth, Development And Performance. Asia Pacific J Clin Nutr (Suppl 1): 7-12.

Manary, M. J. \& Solomons, N. W. (2009). Gizi Kesehatan Masyarakat, Gizi dan Perkembangan Anak. Penerbit Buku
Kedokteran EGC. Terjemahan Public Health Nutrition, Editor. Gibney, M.J, Margetts, B.M., Kearney, J.M. \& Arab, L Blackwell Publishing Ltd, Oxford.

Suhardjo. (2003). Perencanaan Pangan dan Gizi. Jakarta: Bumi Aksara.

Schanler, R. J. (2003). The Low Birth Weight Infant. Nutrition In Pediatrics Basic Science And Clinical Applications. Walker, W. A., Watkins, J. B \& Duggan, C. (Ed). BC Decker Inc, Hamilton, London.

UNSCN. (2008). 6th Report on The World Nutrition Situation, Progress In Nutrition.

Wachs, T. D. (2008). Mechanism Linking Parental Education and Stunting. The Lancet 371: 280. ProQuest

World Health Organization. (2011). World Health Statistic 2011. Geneva.

World Health Organization. (2003). Feeding And Nutrition Of Infants And Young Children. WHO Regional Publications, European Series, No. 87. p. 17.

World Health Organization. (1997). WHO Global Database on Child Growth and Malnutrition. Geneva. 